\title{
The impact of economic policy instruments on the conditions of sustainable economic growth
}

\author{
Armen Altunyan ${ }^{1, *}$ Tatiana Kotcofana $^{I}$, and Viktoria Bazzhina ${ }^{1}$ \\ ${ }^{1}$ Saint-Petersburg State University 7-9, Universitetskaya nab., St. Petersburg, 199034, Russian \\ Federation
}

\begin{abstract}
Given the low rates of economic growth in Russia and the aggravation of the geopolitical situation, the question of the prospects for its stimulation with fiscal and monetary policy tools is of particular relevance. The main priority of the economic policy is to ensure financial stability and prevent destabilization, taking into account the volatility of hydrocarbons prices and the geopolitical tensions. The article uses dialectical materialistic and concrete historical methods to protect that the current economic policies should be focused on sustainable economic growth. It is necessary to form a new strategy of monetary regulation and budget policy that would contribute to the sustainable development of the Russian economy and ensure the economic security of the country. In the perspective of maintaining sustainable economic growth, it is important to solve the problem of equitable distribution, expressed in a strong stratification of society and the violation of social stability, the implementation of economic policy at the level of macroeconomic planning; it is advisable for the Central Bank to follow the link between the possible range of inflation and economic growth; to stimulate consumer and investment demand by reducing interest rates, to form money supply not due to linking gold and foreign currency reserves, but under the issue of securities, to increase budget expenditures and increase public debt for the sake of investment in education and health care.
\end{abstract}

\section{Introduction}

In recent years, there has been an increase in publications and a great interest among economists in studying issues related to social stratification in society, why some countries are rich and others are poor. Work in this direction today is the mainstream of economic and social sciences. The winners of the 2018 Nobel Prize in Economics became Paul Romer and William Nordhaus for Research on Long-Term Economic Growth. Other Nobel Prize winners wrote about it also, such as Joseph Stiglitz, "The Price of Inequality. What the stratification of society threatens our future», «The Great Divide"; Amartya Sen, "The Idea of Justice", Tomas Piketty, "Capital in the 21 st Century" who sees the threat in unleashing heavy social and political implications of increasing inequality in society. Increasing inequality in society, in his view, could contribute also low economic growth [1-4]. From other hand, fast economic growth reduces the role of capital and its endration in private hands.

* Corresponding author: dioskuriya-box@ mail.ru 
The Marxist political economy representing historical development as a struggle of the classes and the resolution of contradictions between productive forces and industrial relations is replaced by the so-called new political economy, founded on the idea of forming institutions, which are forming political power to realize the interests of certain groups. In contrast from Karl Marx, bickering the collapse of the capitalist system, well-known authors propose to suspend unfavorable trends associated with strong social stratification in society

Thus, according to opinion of the authors of the institutional theory of economic growth D. Acemoglu, S. Johnson and D. Robinson: the differences between the growth rates of countries are manifested due to the fact that they have different institutions either contributing to economic growth or suppressing it. They secrete inclusive and extractive institutions. In inclusive institutions, the motivation of economic actors is aimed at creative activity, achieving profitability, administrative pressure and bureaucratic barriers are minimized. All these conditions contribute to economic growth. Extractive institutions suppress incentives to innovate and invest, a narrow group of people make a profit, and as a result, the country's economic growth remains low $[5,6]$.

\section{The problems of economic growth in Russia: the role of fiscal and monetary policy}

We will analyze the state of the Russian economy and the conditions of long-term economic growth for the foreseeable future from the point of view of institutional theory. The growth of the Russian economy from 1999 to 2008 , amounting to about $94 \%$, represented a recovery from the recession of the 1990s. Between 2009 and 2018, the total growth was approximately $6 \%$. We can try to explain this by the consequences of the global financial crisis, the aggravation of the geopolitical situation and the imposition of sanctions against us, but the drop in pace was laid before the aggravation of foreign policy problems and has more structural character. The previous model of economic development has exhausted itself. In the context of low economic growth in Russia, the question of the prospects of its stimulation by economic policy instruments is particularly relevant. In this regard, the discussion among economists about the need for an early transition to a new model of development in the context of growing technological challenges and the aggravation of the geopolitical situation intensified - became active.

With the economy's consistent structure, capital build-up faces the challenge of a fading marginal product. Citing K. Marx: "Having reached the known stage of maturity, the historical form of the process and between man and nature develops further material foundations and its social forms, resets and makes room for a higher shape. The onset of such a crisis is manifested in the expansion and deepening of contradictions and opposites between the distribution relations, and hence the historical form of their respective production relations, on the one hand, and productive forces, productive ability and the development of its factors, on the other hand. Then a conflict erupts between the material development of production and its social form" [7].

This article attempts to find the most effective mechanism for the interaction of fiscal and monetary regulation to ensure the conditions of sustainable economic growth. For that purpose, options for stimulating aggregate demand by fiscal and monetary policy instruments are being considered. The central bank influences inflation by controlling domestic demand through interest rates. The interest rate policy of the Bank of Russia under the inflation targeting regime is focused solely on disinflation, and not on creating the necessary conditions to stimulate aggregate demand. Economic dynamics can be described as inertial, as its accelerated development option is constrained by restrictions on the growth of consumer and investment demand. Let's try to understand these components of aggregate demand and the impact of interest rates on them. 
Real disposable income of the population in 2016 decreased by $5.8 \%$, in 2017 fell by $1.2 \%$, and in 2018 fell by $0.2 \%$. The accumulated depth of compression over the five years exceeded $11 \%$. Population lending growth rate in 2017-2018 were slower, than during the credit boom of 2011-2012. The growth of lending to the population is alarming: 2018 , which was $23 \%$ versus $11 \%$ in 2017 . Although these rates are half as low as in 2011-2012. The current growth is not supported by the increase in real incomes of the population. In the face of stagnant real incomes, perhaps in order to compensate for them, credit to the population has increased. But even relying on this factor, consumer demand is growing weakly. The increase in demand by increasing credit is the most as in 2018 seems unlikely, given the Central Bank's plans to limit lending to individuals, and exhaustion of household credit limit. The deferred demand of high-yielding groups has been realized, and low-income groups are heavily credited and further building up the level of debt burden for them can cause a crisis of non-payments in the banking system. As a result, the ratio of accumulated debt on all loans to individuals to disposable incomes of the population reached a maximum of $29.4 \%$ in 2018 . The ratio of consumer debt to GDP reached its maximum value $-14.4 \%$.

Relative stagnation of incomes of the population affects the domestic market - it does not give incentives to invest into the economy, to make large-scale investments to business. On the part of private business demand for money today is very weak. The price of money for non-financial organizations remains at a higher level than the profitability of most manufacturing industries. And the real rates remain high, which creates unequal conditions for the Russian real sector, worsening its competitive position in world markets.

Interest rates on loans to non-financial organizations are above the profitability threshold of most investment projects. In 2018, the average interest rate on loans to the non-financial sector in Russia was 9\%, which is 2-2.5 times higher than in China and the United States.

Among the factors influencing the decline in the propensity to invest in addition to low domestic demand and high interest rates are the uncertainty of the economic situation. In the context of the Russian economy, the excess of savings over investment plays an important role in improving the investment climate and reducing the level of uncertainty of economic policy. Rising taxes, a long-standing domestic market, and the lack of a state economic development strategy - nothing gives space for investment plans.

As of 2018, Russian enterprises were financed by $52 \%$ of their own funds and only $10.8 \%$ from credit resources. There is a decrease in the propensity to invest from profits, the ratio of investment and profit at face value, for the first half of 2018 was $72 \%$ against $128 \%$ for 2017 , despite the growth of sources of self-financing of investments: growth of balance sheet economy's profit for the first half of 2018 is $35 \%$ higher than the same period in 2017 or $43 \%$ of total fixed investment, the volume of loans attracted by the real sector of the economy was at the end of the 3 rd quarter of 2018 higher by $12 \%$ of the period 2017.

In the face of falling demand for Russian manufacturers' products in 2014-2018 there has been a decline in business revenues and a fall in real incomes of the population. At the same time, the decline in demand for credit has led to the accumulation of free funds of business and population in Russian banks. The result was the accumulation of excess liquidity in bank accounts and the emergence of its structural surplus in the Russian banking system, which began to be observed in Russia from 2017 and 2018, reached 4.2 trillion rubles almost 5\% of GDP. As a result, net pre-tax profit exceeded 1.3 trillion rubles in 2018. Despite the rapid development of the banking system and the growth of public confidence in it, the total assets of banks in relation to GDP from 2015 to 2018 decreased from $99 \%$ to $91 \%$.

The total volume of loans to the economy (non-financial organizations and individuals) reached 48 trillion rubles in 2018. The ratio of loans to the economy to GDP is $46.5 \%$. It should be noted that the financial result of the Russian banking sector in 2015-2018 increased by 7 times, while the financial result of Russian enterprises (without small business entities) increased by only $40 \%$. 
The banking system does not function as a redistribution of money and is able to provide only current activities, but not long-term. The existence of a structured, developed and competitive financial sector is a necessary condition for achieving persistently low rates of price growth. We have a concentration of finance in the narrow segment of the banking sector implemented by the policy of the Central Bank. Diversifying the economy requires long-term loans by increasing equity and attracting long liabilities.

The lack of "long" money in Russia has led to an extremely low rate of investment in fixed capital as a part of GDP (17\% in 2018) Most developed countries have a fixed investment rate of about $20 \%$ of GDP. In Russia, all money is concentrated mainly in the budget and in banks. The preponderance of "short" money in the acute deficit of "long" money leads to increased volatility of all financial indicators, including the exchange rate. There is no such volatility in any country. And this is a big obstacle to the normal development of our economy.

Achieving the inflation target at the expense of the interests of the population and the real sector of the economy can then backfire. Reducing the rate of inflation due to monetary contraction, contrary to the forecasts of the financial authorities, leads not to an increase in investment activity, but to its decline $[8,9]$.

Therefore, it is very important for the Central Bank to maintain a fine line between stimulating the growth of the economy and preventing inflation from increasing. Achieving low inflation is seen as the main monetary policy aims at supporting long-term economic growth. However, an important parameter for the economy is not inflation, but real interest rates for the non-financial sector and the amount of lending to the non-financial sector, which is growing proportionately with the money supply [10]. That is, these important variables for the economy do not depend on inflation in any way. The policy of fiscal and monetary sterilization with the formation of a structural surplus of liquidity in Russia, despite a slight reduction in interest rates, makes credit resources unclaimed and inhibits the potential of financing, which in general, makes it difficult for the domestic economy to develop.

The non-participation of the monetary authorities in the management of economic growth leads to unreasonably low availability of money in the industrial sector and a significant accumulation of funds in the financial sector. The fiscal policy, which is aimed at cutting spending, is also having a deterrent effect on domestic demand. In many countries, fiscal deficits are used to stimulate economic growth. In the Russian Federation for 2019-2021, a surplus of the state budget is planned, which is a tool for withdrawing funds from the economy and acting as a factor of slowing economic growth.

In addition, the Ministry of Finance of Russia in 2018, fulfilling the budget rule, spent about 2 trillion on the purchase of currency in 2018 rubles, sending them to the National Welfare Fund, thereby withdrew money from the economy. However, achieving budget surpluses is not yet a sign of successful economic development.

Although we face ambitious growth targets, the proposed source-building measures could have negative consequences. Since January 1, 2019 VAT increased from 18 to $20 \%$, which according to the calculations of the financial management should bring to the budget annually an additional 600-750 billion of rubles. The increase in VAT can lead to inflation, a further decline in real incomes of the population, a reduction in domestic demand and a slowdown in the growth of the economy. As the main burden of VAT increases will be experienced by high value-added industries, this will reduce their contribution to economic growth and slow down the development of extractive industries, maintaining the raw material orientation of our economy. It should be noted that in China this year it was decided to large-scale reduction of the tax burden by reducing the value-added tax and social insurance deductions. Thus, according to the plans of the Chinese government, the VAT rate for manufacturing industries from April 1 will be reduced from 16 to $13 \%$, and for transport, construction and other industries from $10 \%$ to $9 \%$. 
The policy of fiscal and monetary sterilization with the formation of a structural surplus of liquidity in Russia, despite a slight reduction in interest rates, makes credit resources unclaimed and inhibits the potential of financing, which in generally hampers the development of the domestic economy. In the current Russian situation, demand (both investment and consumer) is below equilibrium as a result of the implementation of tight monetary policy.

Indeed, fiscal demand-stimulating policies without increased productivity and competitiveness can stimulate inflation, but much depends on whether credit opportunities are used not only to increase payment turnover and stimulate consumer demand, but also to increase investment demand and maintain production. In Russia, there is the lack of not only demand, but also supply. Economic growth should also be focused on the manufacturing sector. For a long time, the growing demand in the Russian economy was mainly covered by rising prices and only to a lesser extent by the growth of output. The priority of the national financial system should be the real sector of its own economy.

There is a structural gap between sectors of the economy, where financial resources are concentrated on the one hand and severe shortages on the other. There is a widespread financialization of the economy, characteristic of modern globalization.

The financial sector does not perform the function of optimal allocation of capital and risks and contributes to the further development of "casino finance." It enslaves society and subordinates its logic to the entire economy, which, by this reason, ceases to play its role and contribute to public well-being.

For large banks and speculative funds, the satisfaction of private interests is increasingly at odds with the common good and interests of the economy [11, 12].

So, J. Stiglitz, in his book "The Price of Inequality", notes that financial markets do not pursue the development of the entire economy. They are subject to the ideology of "capital market liberalization" that promotes rapid capital outflows and global governance. Rising inequality is leading to economic turbulence [13]. Economic policy is a reflection and realization of the economic interests of certain groups or sectors.

In Russia, during the period of market reforms there was a significant gap in the rate of gross savings and gross buildups. If in 2010, savings exceeded investments by $6.6 \%$ of GDP, in 2018 it is $9,7 \%$. A high propensity to save on the part of the population has a negative effect on the multiplier of investments. This situation has developed in our country because of the low level of trust on the part of most people to commercial and government structures, many people are not confident in their future and prefer to save money "for a rainy day". There is no mechanism for money transmission to the real economy, which could increase the role of domestic factors for economic growth.

Today, the money accumulated in Russia is large enough to invest. The non-participation of the monetary authorities in the management of economic growth leads to unreasonably low availability of money in the industrial sector and a significant accumulation of funds in the financial sector. Financial and monetary policies should be aimed at ensuring employment and pouring money between sectors of the economy. Therefore, even the minimum level of inflation at high real interest rates and at high absolute price level introduces the real sector and the Russian economy as a whole into a protracted phase of low growth rates.

In today's complex economic and geopolitical situation, socio-economic growth can only be achieved with the use of the institute of planning. State operational planning of the economy and its most important components is the most understandable tool for forming a new model. The increase in healthy protectionism, with the planned concentration of all resources on domestic development priorities, is inevitable. The welfare state is a kind of compromise between a market economy and a planned one. 
The strategic challenges facing the Bank of Russia are determined by the current stage of development of the Russian economy. The existence of a structured and competitive financial sector is a prerequisite for achieving persistently low price growth. In this regard, it is necessary to form a new monetary regulation strategy that would contribute to the sustainable development of the Russian economy and, above all, its real sector. Ensuring price stability should be the main, though not the only goal of the Central Bank. In the meantime, the Government has chosen the main priority of economic policy to ensure financial stability and prevent destabilization, taking into account the volatility of the dynamics of hydrocarbon prices and the aggravation of the geopolitical situation.

If the Russian political elite of 1990, instead of adopting the western model of consumption, copied the western production system, the economic conditions in the country would be much better. Russia, unfortunately, continues to make the same mistakes that it made at that time, guided by wrong economic theories [14].

In addition, in the long term of maintaining sustainable economic growth, it is important to address the problem of equitable distribution, expressed in a strong stratification of society and the disruption of social stability. Low inflation is achieved by impoverishing the population, reducing the solvent demand of the population, real disposable income, by drying the economy. Inflation should remain low not only by reducing demand. Increased income inequality, which increases the propensity to save the rich and reduces consumer demand from the poor, leads to long-term stagnation. For developed countries, given the high debt load, the ability to stimulate aggregate demand by fiscal policy measures is reduced. For the Russian economy, with low standards and the structure of household consumption and underfunding of investment projects, post-Keynesian recommendations are very significant and relevant. The transition to economic growth requires maintaining demand, and in this respect Keynesian ideas remain in demand in Russia [15]. With the current low level of wages, there is no need to rigidly link the level of real wages and productivity. It is important that the level of labor costs in the cost structure does not increase. Household consumption accounts for about $50 \%$ of GDP. In the face of stagnant incomes, economic growth seems difficult to achieve.

As noted by the winner of the Nobel Prize in Economics J. Stiglitz: "You can't revive the growth of the economy by saving on demand, which leads to a further decline in production and employment." The main objective of monetary policy is unemployment, not inflation. It has long been on the agenda, and the significance of this conclusion has been sharply updated in recent times, as in many countries of the world continue to operate purely monetarist recipes for suppressing non-monetary inflation by monetary methods [16].

N. Roubini gave a successful and complete explanation for the increase in growth in the leading countries: "The current acceleration of economic growth is caused by an increase in aggregate demand, which is the result of the continuing expansionary monetary and fiscal policy, and also an increase in business and consumer confidence." Important financial problems such as overcoming the budget deficit, reducing inflation, maintaining an acceptable amount of public debt, etc., are secondary and can only be solved against the background of high growth rates of the Russian economy [17].

In the context of a fairly active anti-inflationary policy implemented by the Bank of Russia in 2014-2017, the drop in demand led to a slowdown in the growth of fixed investment. At the same time, the main source of deteriorating investment dynamics is now large enterprises, which have slowed the growth of purchases of machinery and equipment. This primarily affected construction, the production of innovative goods and manufacturing. Therefore, the transition to a new model of economic development based on domestic sources of development in Russia is not possible. And the main reason is in the plane of the existing interest policy of the Bank of Russia. 
The need for further rate cuts is obvious. At the same time, the reduction of interest rates will not lead to an increase in inflation. The difference in interest rates in the Russian and foreign markets creates great opportunities for high income for participants in speculative carry trade operations, which leads first to inflating and then to the collapse of our stock and currency market. With a significant liquidity surplus, credit, currency and interest risks created by internal and external factors, the Bank of Russia's interest rate policy should change dramatically in the medium term.

In the current situation, the country's economy is operating at half capacity due to the lack of credit to finance working capital and fixed capital investments. The decline in inflation was achieved at the cost of suppressing the final demand from the impoverished population and the enterprises that stopped investing. The transmission mechanism of the banking system, designed to transform savings into investments does not work.

The policy of fiscal and monetary sterilization with the formation of a structural surplus of liquidity in Russia, despite a slight reduction in interest rates, makes credit resources unclaimed and inhibits the potential of financing, which in generally hampers the development of the domestic economy.

Important financial problems such as overcoming the budget deficit, reducing inflation, maintaining an acceptable amount of public debt, etc., are secondary and can only be solved against the background of high growth rates of the Russian economy.

Assessing the provisions of the main directions of the single state monetary policy for the next three years, it can be noted that it will maintain a moderately rigid scenario. It will result in a new round of stagflation, economic degradation and falling living standards. At the same time, foreign speculators will continue to extract super profits on the manipulation of the Russian financial market and the ruble exchange rate. The argument, cited in the justification of the regime of free float of the ruble exchange rate, that it is possible to manage only one parameter of monetary policy - the key rate, within the framework of inflation targeting raises some doubts. It is necessary to use as management parameters not only the key rate, but also the ruble exchange rate, the increase in the monetary base, the rules of reservation of the currency position, and as a target - not only the level of inflation, but also the increase in investment, the level of the economic growth [18].

\section{Conclusion}

There is a potential for Russia's economy to grow, but ideological disunity in theoretical approaches is hindered $[19,20]$. We must learn from reality, not rely on a theory divorced from reality. In this situation, taking into account the peculiarities of the Russian economy, the most adequate seems

- to build economic policy at the macroeconomic planning level. Development policy is a combination of planning and market self-organization.

- the transition to domestic monetary growth mechanisms, targeted credit emission, increased level of monetization of the economy, the formation of long money, are likely to contribute to the implementation of industrial policy priorities and facilitate sustainable economic development [21].

- it is advisable for the Central Bank to stick to linking the possible range of inflation and economic growth. It is not just the reduction of inflation that becomes fundamental, but the growth of investment activity at the expense of the credit component [22].

- to stimulate consumer and investment demand by lowering the interest rate, to form a monetary supply not by binding gold and foreign exchange reserves, but to issue securities - during the period of economic recovery, abandon the excessive conservative "budget rule", increase budget expenditures and increase the national debt for the sake of investments in education, health and other structural reforms. The amount of increase in budget expenditures 
should be approximately equal to the growth of budget investments and real cash incomes of the population [23].

The article was prepared with the financial support of the Russian Foundation for Basic Research (project 19-010-00751 \19).

\section{References}

1. W. Nordhaus, P. Romer, The Sveriges Riksbank prize in economic sciences in memory of Alfred Nobel. Scandinavian Journal of Economics , 121, 857-858 (2019)

2. J. Stiglitz, The origins of inequality, and policies to contain it. National Tax Journal, 68, 425-448 (2015)

3. A. Sen, The idea of justice: a response. Philosophy \& Social Criticism, 41, 77-88 (2105)

4. T. Piketty, L. Yang, G. Zucman, Capital accumulation, private property, and rising inequality in China. American Economic Review, 109, 2469-2498 (2019)

5. D. Acemoglu, J. Robinson, Why some countries are rich and others are poor (Moscow, 2016)

6. D. Acemoglu, S. Johnson, J.A. Robinson, Institutions as the fundamental cause of long run growth. Handbook of Economic Growth (Amsterdam, 2005)

7. K. Marx, F. Engels, Complete Collection of Works, i.e. 23, P. I, p. 456

8. A.N. Lyakin, Rossiyskaya ekonomika posle vosstanovleniya: vremennoye zamedleniye ili novaya trayektoriya rosta. Vestnik S.-Peterb. un-ta. Seriya.5.Ekonomika, 4, 55-70 (2013)

9. N. Bernards, The poverty of fintech? Psychometrics, credit infrastructures, and the limits of financialization. Review of International Political Economy, 26, 815-838 (2019)

10. A.G. Altunyan, Prioritety monetarnoy politiki v kontekste natsional'nykh interesov. Vestnik S.-Peterb. un-ta. Seriya 5. Ekonomika, 1, 103-115 (2015)

11. M. Chesney, De La Grande Guerre À La Crise Permanente, PPUR, (2015)

12. A.A. Rampini, S. Viswanathan, Financial intermediary capital. Review of Economic Studies, 85, 1937-1970 (2018)

13. J. Stiglitz, The price of inequality (Eksmo, 2015)

14. E.S. Reinert, Spontaneous Chaos: The Recession-era economy (Moscow, 2017)

15. V. T. Ryazanov, Keynsianskaya ekonomicheskaya teoriya i politika: vozmozhnosti i ogranicheniya na sovremennom etape. Vestnik S.-Peterb. un-ta. Seriya 5. Ekonomika, 2, 3-26 (2016)

16. J. Stiglitz, Steep peak: America and the new economic order after the global crisis (Exmo, 2011)

17. N. Roubini What have we learned?: Macroeconomic policy after the crisis. 2nd Conference on Rethinking Macroeconomic Policy II, Int Monetary Fund, Washington, DC, 209-222 (2014)

18. J. Majerova, Comprehensive Proposal of Activities of Product Brand Policy in Conditions Specific to Slovak Republic. In 2nd International Conference on Economics and Social Science (ICESS) (Shenzhen, China, 3-8, 2014)

19. M. Skare, M. Porada-Rochoń, Financial and economic development link in transitional economies: A spectral Granger causality analysis 1991-2017, Oeconomia Copernicana 10, 7-35 (2019) 
20. B. Neary, J. Horak, M. Kovacova, K. Valaskova, The future of work: Disruptive business practices, technology-driven economic growth, and computer-induced job displacement, Journal of Self-Governance and Management Economics 6, 19-24 (2018)

21. I. Semenenko, R. Halhash, K. Sieriebriak, Sustainable development of regions in Ukraine: Before and after the beginning of the conflict, Equilibrium. Quarterly Journal of Economics and Economic Policy, 14, 317-339 (2019)

22. S.K. Singh, D. Tripati Rao, Is monetary policy symmetrical in its effect on sectoral output?, Economics, Management, and Financial Markets 13, 11-31 (2018)

23. D. Popescu Ljungholm, Sharing economy, regulatory arbitrage, and urban governance: How city space shapes economic growth and innovation, Geopolitics, History, and International Relations 10, 174-180 (2018) 